\title{
An Investigation of English-Majored Students' Learning Styles and Their Preferable Interaction Activities: A Case Study in the Mekong Delta of Vietnam
}

\author{
Nguyen Ngoc Khanh ${ }^{1}$, Luu Nguyen Kha $\mathrm{Vy}^{2}$,Le Thanh Thao ${ }^{3}$, Le Xuan Mai ${ }^{4}$ \\ ${ }^{12}$ Bachelor, School of Foreign Languages, CanTho University, Vietnam \\ ${ }^{3}$ Master, Academic Department, Gia Viet English Centre, Vietnam \\ ${ }^{4}$ Doctor, Can Tho University, School of Foreign Languages, Vietnam
}

\begin{abstract}
Many changes have been observed in the Vietnamese education context. As a result, higher education institutions implemented many innovations in English teaching and learning, such as new course books, new programs, and new teaching techniques. Somehow, it creates several challenges for English as a foreign language (EFL) students and their motivation for learning. Learning styles have been considered as one of the course factors. The current study attempted to investigate English-majored students' learning styles and their preferred interaction activities in EFL classes. The study was administered as a concurrent nested design in which the qualitative strand is embedded within the prominence of the quantitative one. There were 191 students, studying English high-quality programs in a public tertiary institution in the Mekong Delta of Vietnam, who were recruited in this research. the results from questionnaires including thirty-one close-ended items and two open-ended ones showed that among the students, there are more visual learning styles than the counterparts, including auditory and kinesthetic ones. In terms of interaction activities in EFL classes, games are dominant. Based on the findings, some discussions and implications are presented at the end of the paper.
\end{abstract}

Keywords - English-majored students' motivation, English studies (high-quality program), learning styles, Mekong Delta - Vietnam, interaction activities

\section{BACKGROUND OF THE STUDY}

Many English language teaching (ELT) pedagogical reforms were offered in Vietnam's National Foreign Languages 2020 Project (NFLP 2020), such as establishing high-quality training programs in English, teaching English as a mandatory subject in the school curriculum, employing either untrained or partially trained English native speakers as EFL teachers, increasing instructional ampere-hours, using new textbooks, applying the learner-centered task-based method, maximizing learners' exposure to English in-and-outside of the classrooms, and developing a language proficiency test called Vietnamese Standardized Test of English Proficiency (VSTEP) which was modified from the Common European Framework of Reference (CEFR) ([1],[2]). However, the results of the intervention are still far from the expectations [2]. Besides teachers' factors such as their competency or their responses to change, students' willingness to learn, students' interests, or students' motivation is able to explain the unsuccessful teaching and learning process [3].

Reference [4] said that students refuse to continue learning because their fundamental psychological needs and expectations are not met. Therefore, in case of that teachers can establish a learning environment that helps students meet both, it may bring a glimpse of hope that students can increase their learning outcomes. However, the mission that teachers understand students' expectations or needs is not easy. Reference [5] explained that students' psychology is complicated. As a piece of evidence, some students are delighted by performing better than what their best friends can do; on the other side, some just need to do a completed task to be happy. Consequently, to meet students' expectations and enhance their motivation for learning, several studies have been administered ([3], [4], \&[5]). As a result, many suggestions to help improve students' motivation have been discussed and successfully applied. Reference [5] also indicated that educators should not stop learning about this issue, especially in the case of new pedagogical reforms which are rapidly introduced. 
DOI: $\underline{10.51386 / 25815946 / i j s m s-v 4 i 4 p 107}$

One factor affecting students' learning motivation is their learning styles [6]. The differences in the ways each student desires to learn to require teachers to make precise decisions in the process of learning to avoid demotivating their students [7]. Reference [8] stated that each student needs different types of teaching methods and instructional materials. Regarding high awareness of what role learning styles are playing in learning and teaching, many researchers dedicated themselves to explore many different learning styles and their features ([9],[10],\& [11]). However, it seemed difficult to find a specific scientific paper administering in the Vietnamese education context. To fill in this gap, the current study was conducted in a university in the Mekong Delta, Vietnam. Especially, the study aims to explore the learning styles of English-majored students who are studying high-quality programs.

\section{Motivational RESEARCH}

References [12], [13] and [14] share the same idea of motivation that it is the mechanisms that lead people's behaviors. There have been some studies of students' awareness of these mechanisms through their desire for success and their appreciation of the actions [15]. Students' expectation and their evaluation of results become the relationship, called the "expectancy-value model of motivation" [16]. According to [17], people strive to achieve objectives they have set for themselves. The target of motivation mentioned to the extent to which an individual's expectation of the outcome of motivation is self-directed, or being targeted at goals outside of the context of immediate work tasks ([18]; [19]). Motivation is a significant component affect the success of second language learning. It covers such aspects as energy, direction, persistence, activation, and also intention [19]. Reference [20] suggested that motivation has a positive impact on workers' job-related outcomes, such as work performance, productivity, and persistence. Reference [21] defined motivation as the presence of enthusiasm that drives employees to put in extraordinary effort to deliver results. Reference [22] stated that motivational factors are reflected by the values, expectations, and career-related goals, and their attitudes towards education. In the other words, motivation is a directed-goal behavior towards a specific goal.

\section{LEARNING STYLES AND INTERACTION ACTIVITIES}

Reference [6] ascertained that among factors differing students from each other, learning styles play the most essential one. Reference [23] defined learning styles as students' cognitive, affective, and physiological characteristics that are relatively stable indicators of how learners think of, deal with, and react to the learning environment. In the study of [8], the term learning styles was used to talk about the ways helping match teaching techniques and instructions to different students' needs. Reference [24] defined learning styles as a concept describing the differentiation among learners in using one or more strategies to understand, reconstruct, and remember knowledge. The definition of learning styles was simplified by [25] as the educational conditions under which a student is most likely to learn. Reference [26] claimed, "Different students have different modes of learning, and their learning could be improved by matching one's teaching with that preferred learning mode". In short, learning styles are the ways students prefer using to acquire knowledge.

Reference [27] confirmed that every student has a particular style of learning - it simply plays as an identity. Acknowledging the variation of students' learning styles throughout their learning strategies, EFL teachers can manage their classrooms to respond to their demands of interaction activities related to sound, illumination, temperatures, seating work, movements, or grouping. Besides, EFL teachers can identify the patterns in which students tend to stay concentrated best-individual work, pair work, small group discussion, or big group interaction. Moreover, EFL teachers have an opportunity to reflect on what they should do in classes to fit with the students' learning styles and promote their learning. Furthermore, it increases EFL teachers' awareness of what strategies students use to remember the lessons, by speaking, seeing, manipulating, writing, note-taking, experiencing, and multi-using different types of strategies. Furthermore, students' motivation for learning is encompassed by their learning styles in terms of types of tasks, learning workloads, or the extent of suitability of teachers' requirements.

Therefore, it increases the need for understanding students learning styles. The next section comprises different styles in VAK theory for suggesting the main framework in the current study.

\section{VAK THEORY OF LEARNING STYLES}

VAK theory of learning styles was introduced to explain the differences in students' learning styles [28]. VAK stands for visual, auditory, and kinesthetic and VAK theory is considered to be one of the classical learning theories in the educational field [6]. Specifically, the differences were explained as follows in [6]. 
DOI: $\underline{10.51386 / 25815946 / i j s m s-v 4 i 4 p 107}$

Visual: Visual learners store and remember lessons through visual aids like graphics, pictures, and texts. However, they have problems with the information given in lectures, conversations, and oral mood without any visual support.

Auditory: Auditory learners prefer oral moods and sounds. They prefer to listen to lectures and discussions. Also, recorded books are encouraged to use to teach this type of learner.

Kinesthetic: Kinesthetic learners have a great desire in touching things, doing actions, and moving around rather than listening or reading. These learners are very active and enthusiastic but they quickly become tired and require breaks.

Reference [29] indicated that the model focuses on the modes or senses through which people receive and process information. Reference [30] described a VAK learning style as the perceptual, instructional preference model used to distinguish different types of learners' learning by their sensory preferences. Reference [31] proposed that every person has a preferred learning style that may be aligned with others. Reference [32] stated that the model can be used to support the incorporation of different learning techniques into classroom instruction and activities. It can simplify the model as a diagram of how students learn by receiving vision, hearing sounds, and touching things.

\section{RELATED STUDIES}

The number of studies covering the impact of learning styles on students' motivation is not small. Reference [29] conducted a study using the VAK theory to investigate students' learning styles in some elementary and high schools. The results showed that $29 \%$ of elementary and high school learner are visual learner, $34 \%$ are auditory, and the remaining 37\% are kinesthetic learner. It can be concluded that kinesthetic and auditory learning styles are preferred rather than visual ones.

Similarly, a study by [33] used a VAK learning model in examining the learning style preferences of adults. Moreover, the learners in this study reported that they found it extremely difficult to learn English. The study showed that more participants preferred learning by visual aids and recordings than going around the classrooms or doing actions. Interestingly, this study also found that some students have multimodal learning styles. It means that they preferred more than one style of learning.

Reference [34] employed a case study, designed as a qualitative approach, to figure out whether Vietnamese non-English majored collegiate freshmen prefer to be passive or active. Two freshmen, a girl, and a boy were invited to partake in the semi-structured interviews. The study found that Vietnamese freshmen are active and they do not learn by heart. They usually keep silent because of the nature of their learning styles, and sometimes, that of their teachers' questions. Besides, the authors assumed that Vietnamese students' personalities and their perspectives of the suitability of group work may affect their willingness to participate in the team working activities. Learning by heart is required to avoid receiving low marks from their teachers, not their will. They prefer learning to understand and use other strategies to help improve their knowledge, rather than rote learning.

The impact of learning styles on students' motivation as well as their learning outcomes has been widely investigated, even in the Vietnamese context. However, just a few studies were observed to examine Vietnamese students from the South of Vietnam. Though in the Vietnamese context, [34] did dedicate to the literature related to non-English-majored students' learning styles, the sample is too small to generalize the findings. Besides, in the context that the Vietnamese government is implementing numerous reforms to enhance the proficiency of Vietnamese people as well as making several changes in higher education institutions, a need for exploring English-majored students' learning styles in the context of a university is recognized. For the reasons abovementioned, this study was conducted to investigate the impact of students' learning styles on their motivation for learning English in a public tertiary university.

\section{Methodology}

\section{Research design}

The current study was administered as a concurrent nested design in which the qualitative strand is embedded within the prominence of the quantitative one. According to [35], this type of mixed-method approach is used to 
DOI: $\underline{10.51386 / 25815946 / i j s m s-v 4 i 4 p 107}$

Volume: 4 Issue: 4

July to August 2021

https://www.ijjsmsjournal.org

ratify, support, and approve the findings of each other. According to [36], a quantitative design is useful for generalizing to a large population because it involves a larger sample that is randomly selected. Besides sampling, it does not take much time in data analysis as it uses statistical software such as SPSS [37]. Meanwhile, qualitative data offers insightful perspectives on the research topic and provides details of the situation. As the benefits abovementioned, this design was conducted to investigate English-majored students' preferred learning styles and their favorite types of activities in EFL classes.

\section{Participants}

All participants are English-majored students from cohorts 44, 45, and 46 in a public university in the Mekong Delta, Vietnam. The information of the participants is displayed in Table I.

TABLE I

PARTICIPANTS' INFORMATION

\begin{tabular}{|c|c|c|c|c|c|}
\hline Variables & Sub-variables & $\begin{array}{c}\text { Cohort } 44 \\
(\mathrm{~N}=84)\end{array}$ & $\begin{array}{c}\text { Cohort } 45 \\
(N=73)\end{array}$ & $\begin{array}{c}\text { Cohort } 46 \\
(\mathrm{~N}=34)\end{array}$ & $\begin{array}{c}\text { Total } \\
(\mathrm{N}=191)\end{array}$ \\
\hline \multirow{2}{*}{ Gender } & Male & 12 & 22 & 11 & 45 \\
\hline & Female & 72 & 51 & 23 & 146 \\
\hline \multirow{4}{*}{ GPA } & Excellent & 26 & 6 & 9 & 41 \\
\hline & Very good & 33 & 27 & 18 & 78 \\
\hline & Good & 25 & 40 & 5 & 70 \\
\hline & Quite good & 0 & 0 & 2 & 2 \\
\hline \multirow{4}{*}{$\begin{array}{l}\text { English } \\
\text { proficiency }\end{array}$} & Elementary & 6 & 27 & 8 & 41 \\
\hline & Intermediate & 45 & 32 & 20 & 97 \\
\hline & Upper-intermediate & 31 & 14 & 6 & 51 \\
\hline & $\begin{array}{l}\text { Estimated outcomes for a } \\
\text { bachelor }\end{array}$ & 2 & 0 & 0 & 2 \\
\hline
\end{tabular}

As observed in Table I, 191 participants, 84 students from cohort 44, 73 for cohort 45, and 34 others who are studying in the cohort 46 , were employed to take part in the current study. They are categorized into three variations, gender (45 males and 146 females), GPA (41 excellent students, 78 very good students, 70 good students, and 2 for quiet good ones), and English proficiency (41 students at elementary level, 97 intermediate students, 51 students with upper-intermediate level, and 2 students who are estimated outcomes for a bachelor). All of them are English-majored students who are studying in a tertiary higher education institution in the Mekong Delta, Vietnam.

Additionally, the participants almost studied all subjects in English in their first two years. Besides, they had opportunities to learn about soft skills, cultures of English-speaking countries, and knowledge of English, including phonetics, syntax, morphology, and so on. Moreover, the juniors had to learn specialized subjects that require critical thinks and professional skills. However, not all of the students were excellent in academic performance or could keep up with the lessons.

\section{Data collection instrument}

A questionnaire with 5-point Likert scale including thirty-one closed-ending items related to the research aims was used to collect data. The items were divided into three clusters, including the first twenty-four items for investigating students' learning styles and the next seven items for examining students' preferable interaction activities. Besides, the questionnaire also consists of two opened-ending items to explore the indepth perspectives of the participants (see Appendix 1).

\section{Procedures}

The procedures of this study were administered in seven steps and they are displayed in Figure 1. 


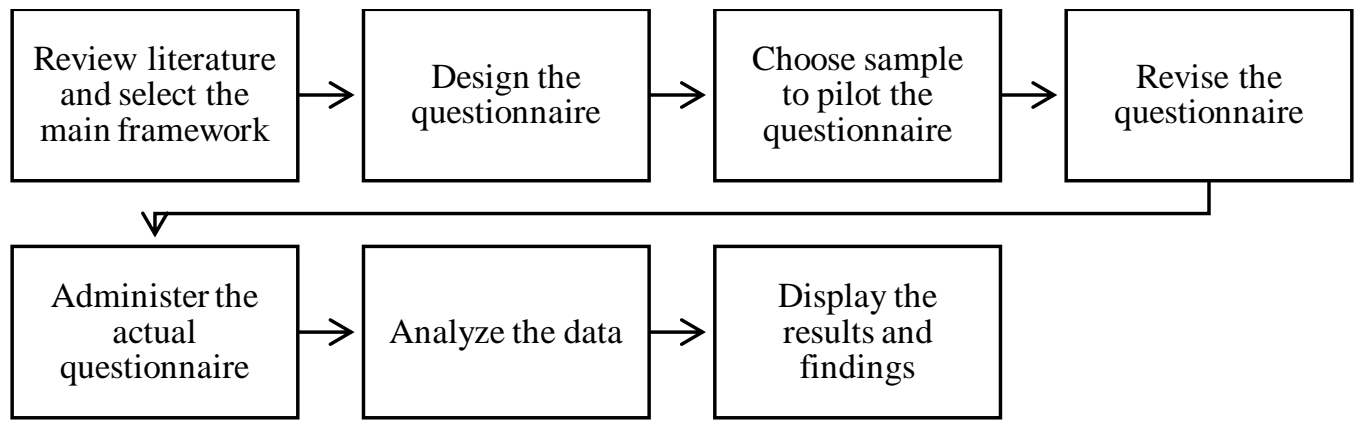

Fig. 1 Procedures

As observed in Figure 1, first and foremost, the researchers reviewed some reliable frameworks to find out the most appropriate ones for the study. Next, the questionnaire was designed based on the chosen framework. Then, a sample of participants who are different from the actual ones was kindly invited to pilot the reliability and validity of the instrument. After collecting the piloting data and feedback from the piloting participants, the questionnaire was revised and proofread by all members of the research team. Because of the time constraints and COVID-19 pandemic, the second round of the pilot process was canceled. However, the revised questionnaire was sent back to the piloting participants through the Google Form platform to recheck. Consequently, no requirement for reediting the questionnaire. Therefore, the research team was confident enough to employ it to the actual participants. After two weeks, the researchers informed to stop receiving new respondents and started to analyze the collected data. Before the results of the study were presented in this paper, a Scale test was run on the respondents to check whether the results are reliable. What observed in the results of the test $(\alpha=.76)$ confirmed the reliability of the results in the current study.

\section{RESULTS}

The process of data analysis started with the investigation of the participants' favored learning styles. Their preferable interaction activities would be analysed right after that.

\section{Participants' favored learning styles}

A Descriptive Statistics test was run on the first twenty-four items to check the average mean score of students' preferred learning style among VAK. The results are displayed in Table II.

TABLE II

\section{PARTICIPANTS' LEARNING STYLES}

\begin{tabular}{|c|c|c|c|c|c|}
\hline Learning styles & $\mathbf{N}$ & Minimum & Maximum & Mean & Std. Deviation \\
\hline Visual & 191 & 1.50 & 4.75 & 3.06 & .70 \\
\hline Auditory & 191 & 1.50 & 4.75 & 3.05 & .69 \\
\hline Kinesthetic & 191 & 1.50 & 4.50 & 2.90 & .65 \\
\hline Overall & $\mathbf{1 9 1}$ & $\mathbf{1 . 8 3}$ & $\mathbf{4 . 4 2}$ & $\mathbf{3 . 0 0 3 1}$ & $\mathbf{. 5 0 2 6 5}$ \\
\hline
\end{tabular}

Table II shows that the overall mean score of the participants' learning style is at a moderated level $(\mathrm{M}=3.00)$. Next, a One-Sample T-test was administered to check whether there was any difference between the mean score of 3.00 and the test value 3.6, the accepted mean score of a high level [38]. The results of the test showed that no significant difference occurred between the two variables $(\mathrm{t}=-16.41 ; \mathrm{df}=190 ; \mathrm{p}=.00)$. In conclusion, the participants just agreed that they belong to these learning styles at a medium level.

In Table II, the highest mean score belonged to visual style $(\mathrm{M}=3.06)$, followed by that of the auditory style $(M=3.05)$. The kinesthetic one got the lowest mean score $(M=2.90)$. It can be inferred that the participants perceived visual style as their learning style higher than their counterparts. In other words, most of the students prefer studying with the support of visual aids like graphics, pictures, and texts. On the other hand, the students seemed to be uncomfortable with touching things, doing actions, and moving around. 
DOI: $\underline{10.51386 / 25815946 / \mathrm{ijsms}-\mathrm{v} 4 \mathrm{i} 4 \mathrm{p} 107}$

Volume: 4 Issue: 4

July to August 2021

https://www.ijsmsjournal.org

The respondents in the "Others" items also displayed the same results that the participants preferred studying with visualization. Most of them wrote that they usually watch movies, read manga, or take notes the lessons by drawing.

Next, One-Way ANOVA tests were run to check whether participants with different cohorts, genders, GPAs, and English proficiency are distinct from their counterparts or not. The results of the tests were displayed in Table III.

TABLE III

LEARNING STYLES ACCORDING TO VARIABLES

\begin{tabular}{|c|c|c|c|c|}
\hline Variables & Sub-variables & Number & Mean & p-value \\
\hline \multirow{3}{*}{ Cohort } & K44 & 84 & 2.87 & \multirow{3}{*}{.00} \\
\hline & K45 & 73 & 2.95 & \\
\hline & K46 & 34 & 3.46 & \\
\hline \multirow{2}{*}{ Gender } & Male & 45 & 3.00 & \multirow{2}{*}{.99} \\
\hline & Female & 146 & 3.00 & \\
\hline \multirow{4}{*}{ GPA } & Excellent & 41 & 3.03 & \multirow{4}{*}{.58} \\
\hline & Very good & 78 & 3.01 & \\
\hline & Good & 70 & 2.97 & \\
\hline & Quite good & 2 & 3.45 & \\
\hline \multirow{4}{*}{$\begin{array}{c}\text { English } \\
\text { proficiency }\end{array}$} & Elementary & 41 & 3.04 & \multirow{4}{*}{.38} \\
\hline & Intermediate & 97 & 3.03 & \\
\hline & Upper-intermediate & 51 & 2.91 & \\
\hline & Estimated outcomes for a bachelor & 2 & 3.33 & \\
\hline
\end{tabular}

As observed in Table III, the factors including gender, GPA, and English proficiency did not differentiate the participants' learning styles $(\mathrm{p}=.99 ; \mathrm{p}=.58 ; \& \mathrm{p}=.38$ respectively). However, a significant difference was found in the remaining variable, cohort $(\mathrm{p}=.00)$. It can be inferred that the participants from different cohorts have different learning styles.

Related to the differentiation abovementioned, the mean score of the participants from cohort 46 was the highest one $(M=3.46)$, followed by that of those from cohorts 44 and $45(M=2.95 \& M=2.97$ respectively). In other words, the ones from cohort 46 identified their learning styles clearer than their seniors.

Then, to find out the difference in preferable learning styles among the cohorts, One-Way ANOVA tests were run on the items representing each style. The results of the tests were presented in Table IV.

TABLE IV

LEARNING STYLES AMONG THREE COHORTS

\begin{tabular}{|c|c|c|c|c|}
\hline Learning styles & Cohorts & Number & Mean & p-value \\
\hline \multirow{3}{*}{ Visual } & K44 & 84 & 2.96 & \multirow{2}{*}{.00} \\
\cline { 2 - 4 } & $\mathrm{K} 45$ & 73 & 2.95 & \\
\cline { 2 - 4 } & $\mathrm{K} 46$ & 34 & 3.53 & \multirow{2}{*}{.00} \\
\cline { 2 - 4 } Auditory & $\mathrm{K} 44$ & 84 & 2.89 & \\
\cline { 2 - 4 } & $\mathrm{K} 45$ & 73 & 3.01 & \multirow{2}{*}{.00} \\
\cline { 2 - 4 } & $\mathrm{K} 46$ & 34 & 3.52 & \\
\cline { 2 - 4 } & $\mathrm{K} 44$ & 73 & 2.74 & \\
\hline
\end{tabular}


DOI: $\underline{10.51386 / 25815946 / i j s m s-v 4 i 4 p 107}$

Volume: 4 Issue: 4

July to August 2021

https://www.ijjsmsjournal.org

Based on the results in Table IV, the participants from cohort 46 with the highest mean scores, M=3.53 for visual style, $M=3.52$ for auditory style, and $M=3.32$ for kinesthetic style, were in favor with all learning styles more than the ones from cohorts 44 and 45 ( $\mathrm{p}=.00$ for all). It included that the participants from cohort 46 enjoyed their classes with visual aids like graphics, pictures, texts, oral moods, sounds, touching things, doing actions, and moving around more than their counterparts could do in the current study.

To sum up, the participants' perceptions of the VAK theory of learning styles were not high. Among the three types of learning styles proposed in the current study, there are more learners preferring visual ones than their counterparts. Besides, the participants shared that they would like to watch movies, read manga, and take notes to summarize the lessons. Next, it was shown that the participants differed from each other by their learning cohorts. Specifically, those from cohort 46 declared their willingness to take part in all kinds of teaching materials that their teachers use in EFL classes. On the other side, the willingness of students from cohorts 44 and 46 in partaking these activities was not at that high level.

\section{Participants' preferable interaction activities}

This cluster comprises items representing seven interaction activities in the EFL classroom, including individual work, pair work, group work, small group discussion, quizzes, presentations, and games. A Descriptive Statistics test was run on the cluster and its results were shown in Table V.

TABLE V

\section{PARTICIPANTS' PREFERABLE INTERACTION ACTIVITIES}

\begin{tabular}{|c|c|c|c|c|c|}
\hline Activities & $\mathbf{N}$ & Minimum & Maximum & Mean & Std. Deviation \\
\hline Games & 191 & 1.00 & 5.00 & 4.46 & .38 \\
\hline Quizzes & 191 & 1.00 & 5.00 & 4.10 & .68 \\
\hline Group work & 191 & 1.00 & 5.00 & 3.81 & .84 \\
\hline Pair work & 191 & 1.00 & 5.00 & 3.70 & .88 \\
\hline Group discussion & 190 & 1.00 & 5.00 & 3.51 & .94 \\
\hline Individual work & 191 & 1.00 & 5.00 & 2.97 & 1.01 \\
\hline Presentations & 191 & 1.00 & 5.00 & 2.93 & 1.00 \\
\hline Overall & $\mathbf{1 9 1}$ & $\mathbf{1 . 5 7}$ & $\mathbf{5 . 0 0}$ & $\mathbf{3 . 6 4}$ & $\mathbf{9 5}$ \\
\hline
\end{tabular}

Table $\mathrm{V}$ displays that the overall mean score of the interaction activities proposed in this study is medium $(\mathrm{M}=3.64)$. To check whether the mean score is different from the test value 3.6, accepted as a high level of perceptions (Oxford, 1990), a One-Sample T-test was employed. The results of the test indicated that the mean score $(\mathrm{M}=3.64)$ is not different from the test value $3.6(\mathrm{t}=.51 ; \mathrm{df}=190 ; \mathrm{p}=.61)$. It can be concluded that the participants highly preferred these activities.

Related to the results displayed in Table V, the highest mean score belongs to games $(\mathrm{M}=4.46)$, followed by quizzes ( $M=4.10)$, group work $(M=3.81)$, pair work $(M=3.70)$, small group discussions $(M=3.51)$, and individual work $(M=2.97)$. Presentations got the lowest mean score $(M=2.93)$. The results lead to an inference that the participants preferred games the most and abhorred presentations in vice versa.

In the "Others" item for getting more ideas related to the interaction activities in EFL classes, a new activity different from the proposed ones was figured out. It is a debating or debate competition.

The next One-Way ANOVA tests were used to check whether the factors as different cohorts, genders, GPAs, and English proficiency differ the participants' preferable interaction activities. The results were presented in Table VI. 
DOI: $\underline{10.51386 / 25815946 / i j s m s-v 4 i 4 p 107}$

TABLE VI

PARTICIPANTS' PREFERABLE INTERACTION ACTIVITIES ACCORDING TO VARIABLES

\begin{tabular}{|c|c|c|c|c|}
\hline Variables & Sub-variables & Number & Mean & p-value \\
\hline \multirow{3}{*}{ Cohort } & K44 & 84 & 3.60 & \multirow{3}{*}{.04} \\
\cline { 2 - 4 } & K45 & 73 & 3.82 & \\
\cline { 2 - 4 } Gender & K46 & 34 & 3.34 & \multirow{2}{*}{.80} \\
\cline { 2 - 4 } & Male & 45 & 3.67 & \multirow{3}{*}{.11} \\
\hline \multirow{3}{*}{ GPA } & Female & 416 & 3.63 & \\
\cline { 2 - 4 } & Excellent & 78 & 3.52 & \multirow{3}{*}{.78} \\
\cline { 2 - 4 } & Very good & 2 & 3.70 & \\
\hline \multirow{3}{*}{$\begin{array}{c}\text { English } \\
\text { proficiency }\end{array}$} & Good & 41 & 3.72 & \\
\cline { 2 - 4 } & Quite good & 97 & 3.65 & \\
\cline { 2 - 4 } & Elementary & 2 & 3.53 & \\
\cline { 2 - 4 } & Estimated outcomes for a bachelor & 2.64 & \\
\hline
\end{tabular}

The results in Table VI indicated that gender, GPA, and English proficiency did not differ the participants' preferable interaction activities $(\mathrm{p}=.80 ; \mathrm{p}=.11$; and $\mathrm{p}=.78$ respectively), but their difference in the learning cohorts did in this study $(\mathrm{p}=.04)$. In other words, the participants from different cohorts were in favor of the activities at different levels. Specifically, the sophomores $(M=3.82)$ liked the activities proposed in the current study than the counterparts $(\mathrm{M}=3.60 \& \mathrm{M}=3.34)$.

Next, to examine what types of interaction activities were preferred the most in each cohort, One-Way ANOVA tests were run. The results of the tests were detailed in Table VII.

TABLE VII

COMPARISON AMONG THREE COHORTS RELATED TO INTERACTION ACTIVITIES

\begin{tabular}{|c|c|c|c|c|}
\hline Activities & $\begin{array}{c}\text { K44 } \\
\mathbf{( N = 8 4 )}\end{array}$ & $\begin{array}{c}\text { K45 } \\
\mathbf{( N = 7 3 )}\end{array}$ & $\begin{array}{c}\text { K46 } \\
\mathbf{( N = 3 4 )}\end{array}$ & p-value \\
\hline Games & 4.43 & 4.73 & 3.94 & .02 \\
\hline Quizzes & 4.38 & 4.07 & 3.47 & .03 \\
\hline Group work & 3.33 & 4.29 & 3.94 & .00 \\
\hline Pair work & 4.14 & 3.36 & 3.35 & .02 \\
\hline Small group discussions & 3.41 & 3.85 & 3.00 & .09 \\
\hline Individual work & 3.19 & 2.86 & 2.65 & .35 \\
\hline Presentations & 2.33 & 3.58 & 3.00 & .00 \\
\hline
\end{tabular}

What observed in Table VII shows that small group discussions and individual work were favored at the same level among three cohorts $(\mathrm{p}=.09 \& \mathrm{p}=.35)$. On the other hand, they have different extents in attitudes towards games, quizzes, group work, pair work, and presentations $(\mathrm{p}=.02 ; \mathrm{p}=.03 ; \mathrm{p}=.00 ; \mathrm{p}=.02 ; \& \mathrm{p}=.00$ respectively).

Regarding games, group work, and presentations, cohort 45 liked these types of interaction activities more than their counterparts. Except for games in which students from cohort 46 got the lowest mean score $(\mathrm{M}=3.94)$, those from cohort 44 were observed as the ones are opposed to group work $(\mathrm{M}=3.33)$ and presentations $(\mathrm{M}=2.33)$ the most. Especially, the mean score of cohort 44 in terms of presentations was the lowest mean score among all. 
DOI: $\underline{10.51386 / 25815946 / i j s m s-v 4 i 4 p 107}$

In terms of quizzes and pair work, the participants from cohort 44 liked it the most. On the other hand, those from cohort 46 were not interested in these activities and they got the lowest mean scores in both $(\mathrm{M}=3.47 \&$ $\mathrm{M}=3.35)$. Related to pair work, although cohort $45(\mathrm{M}=3.36)$ had a higher mean score than cohort $46(\mathrm{M}=3.35)$, the difference is too small.

In short, the participants highly perceived these interaction activities in their English learning. And, games are the most preferred one among seven different activities proposed in this study. Among three cohorts, some differences were observed in terms of five interaction activities, including games, group work, presentations, quizzes, and pair work.

The following section would include some discussions regarding the findings of the current study and some reflections on the Vietnamese educational context.

\section{DISCUSSIONS}

In the current study, the participants just perceived their learning styles at a medium level. It leads to an assumption that Vietnamese English-majored students have the capacity to adapt the learning styles to their studying, not depend on a particular one. In higher education institutions in Vietnam, students have to study with a variety of teachers, so it is essential for them to collaborate with different styles of teaching.

The study also figured out that students abominating kinesthetic style are more than the others with auditory and visual styles. It is explained in the paper written by [39] that at a very young age, Asian students, including Vietnamese ones, are taught to be polite, keep silent, listen to their teachers, take notes, reply to the questions given by the teachers when asked. Therefore, they tend to avoid moving around or doing actions in the classroom. However, [34] found that Vietnamese students are usually silent in classes not because they lack interest in the lessons, but sometimes, it dues to their teachers' questions which are not in their favor.

The differentiation in students learning styles caused by the factor related to students' cohorts is one of the remarkable findings of this study. The students from cohort 46 are freshmen who could be the least influenced by the social integration in the school time studying in the university. Reference [40] indicated that the most common thread for students' avoidance to study sophomore year is social integration. It can be inferred that students' motivation for continuous learning in the university, as well as their participation in the in-class activities, is affected by this thread. It could explain the reason why the seniors tended to disagree with all learning styles proposed in this study. However, this is not a good signal for those who are dedicating to help improve students' motivation for learning. The participants lost their motivation because they get older, they become an example for the next generation of freshmen, or the teaching techniques and strategies are problematic. This question should be answered.

Finally, among the interaction activities, the participants were interested in games the most. Reference [41] clarified the important role of gamification regarding English learning, especially in vocabulary learning in the Vietnamese context. This finding also reaffirmed the indication in the study by [41] that Vietnamese students are so-ready for gamified learning, especially computer-assisted language learning (CALL) and mobile-assisted language learning (MALL) in EFL classrooms. On the other hand, the participants of the current study, especially the junior students seemed to be frightened with presentations. The panic with the public speaking techniques as oral presentations showed the chicken-hearted psychology of the English-majored students in this study. Different from these students, [42] conducted a study in Ho Chi Minh city of Vietnam to investigate EFL students' attitudes towards oral presentations that are highly positive. Related to Ho Chi Minh city, it is the key economic region in Vietnam and the job competition there is draconic. Therefore, students are required to train their mentality right from school time. However, in Can Tho city as the research site, although it plays as a central city in the South of Vietnam, the harshness presented seems to be not notable. As an inference, this fact, somehow, decreases the participants' willingness to stand up and talk in front of people. To be fair, EFL teachers need taking responsibility for enhancing their students' confidence and achieve their goals. For that, the alignment of lecturers' efficacy, students' achievements, and lecturers' competencies should be discussed [43]. 
DOI: $\underline{10.51386 / 25815946 / i j s m s-v 4 i 4 p 107}$

\section{IMPLICATIONS AND CONCLUSION}

The current study contributed numerous significant findings which help several types of education stakeholders, such as EFL teachers and their students, school administrators, employment counselors, and researchers who are interested in this field.

First, EFL teachers had an overview of their students' learning styles to be flexible for teaching a particular case. Fortunately, the study found that English-majored students are adaptable to their teachers' teaching styles, even though the motivation seemed to be not high as expected.

Second, EFL students got a good chance to reflect on their learning styles and strategies. Furthermore, it provided them an opportunity to compare themselves to the other students from economic regions and figure out what they should improve.

Third, the next beneficiary is the school/ education institution administrators. For them, the question of whether their employees' teaching techniques are problematic or not requires them to start their actions. Students' persistence to continue their learning so much depends on their motivation. Therefore, the level of motivation dropping would cause the increase of dropout.

Fourth, the employment counselors also got many benefits from the discussions of this study. The comparison between students from two different locations provides them a general view of the quality of human resources in Vietnam. Therefore, it is potential for them to organize some training centers in order to train those who are less qualified to compete.

Finally, the current study provides many significant findings for further studies in the same field to discuss. Furthermore, this study did not use diverse data collecting instruments; therefore, researchers should use observations or interviews to gather data. And, the proposed framework was enriched by the ideas from the participants throughout the qualitative data. Researchers should modify to fulfill their theoretical framework.

In conclusion, it is hoped that the results from this study can benefit different stakeholders, especially the EFL teachers who will provide effective and high quality teaching. Also, the students, particularly those participating in this study can be aware of their preferred learning styles and interaction activities so that they can modify theirs and improve their academic performance.

\section{ACKNOWLEDGEMENT}

NGUYEN Ngoc Khanh is currently studying a high-quality program of English Studies at Can Tho University. Khanh is interested in learning about students' awareness of English and its role in the international integration era.

LUU Nguyen KhaVy is currently studying a high-quality program of English Studies at Can Tho University. $\mathrm{Vy}$ is interested in learning about English language and students' perceptions of effective English learning styles, especially English-major students.

LE Xuan Mai, Head of the Department of General English and English for Specific Purposes, School of Foreign Languages, Cantho University, Vietnam, obtained her doctorate degree in Education in Australia. Her research interests include English language teaching (ELT), ICT in ELT, teacher education, and teacher professional development.

LEThanh Thao is an English instructor at Gia Viet English Centre in Can Tho city. He is also an invited lecturer teaching language skill courses at Can Tho University, Vietnam. Thao is very keen on conducting classroom-based research.

\section{REFERENCES}

[1] C. V.Le, H.T.M. Nguyen, N.T.T. Minh, and Barnard, R. (Eds.), Building Teacher Capacity in English Language Teaching in Vietnam: Research, Policy and Practice (1st ed.), Routledge,2019.

[2] T. T.Le andM. X. Le, English language teaching reforms in Vietnam: EFL teachers' perceptions of their responses and the influential factors, Innovation in Language Learning and Teaching, 1-12, 2020.

[3] L. S. Lumsden,Student Motivation, Research Roundup, 10(3), n3, 1994. 
DOI: $\underline{10.51386 / 25815946 / \mathrm{ijsms}-\mathrm{v} 4 \mathrm{i} 4 \mathrm{p} 107}$

Volume: 4 Issue: 4

[4] J. P. Raffini, Winners without losers: Structures and strategies for increasing student motivation to learn, Allyn \& Bacon, 160 Gould Street, Needham Heights, MA 02194, 1993.

[5] M. L.Maehr andC. Midgley, Enhancing student motivation: A schoolwide approach. Educational psychologist, 26(3-4), 399-427, 1991.

[6] Z.Ghaedi and B.Jam, Relationship between Learning Styles and Motivation for Higher Education in EFL Students, Theory \& Practice in Language Studies, 4(6),2014.

[7] H.McCarty, Motivating your audience: Speaking from the heart, Allyn \& Bacon,1999.

[8] J. R. Kirby, (Ed.), Cognitive strategies and educational performance, Academic Press,1984.

[9] J. M. Reid, Learning styles in the ESL/EFL classroom,Heinle\&Heinle Publishers, International Thomson Publishing Book Distribution Center, 7625 Empire Drive, Florence, KY 41042,1995.

[10] R. C.Scarcellaand R. L. Oxford, The tapestry of language learning: The individual in the communicative classroom,1992.

[11] H. A. Witkin, C. A. Moore, D. R. Goodenough, and P. W. Cox, Field-dependent and field-independent cognitive styles and their educational implications, Review of educational research, 47(1), 1-64, 1977.

[12] A.Bandura, Self-efficacy: toward a unifying theory of behavioral change, Psychological review, 84(2), $191,1977$.

[13] A.Bandura, Human agency in social cognitive theory, American psychologist, 44(9), 1175, 1989.

[14] R.Kanfer, P. L. Ackerman, T. C. Murtha, B.Dugdale, \& L.Nelson, Goal setting, conditions of practice, and task performance: A resource allocation perspective, Journal of Applied Psychology, 79(6), 826, 1994.

[15] P. R. Pintrich, The role of metacognitive knowledge in learning, teaching, and assessing, Theory into practice, 41(4), 219-225,2002.

[16] J. W. Atkinson, An introduction to motivation,1964.

[17] L. W. Rue and L. L. Byars, Management: Skills and application,2000.

[18] A. P.Briefand R. J. Aldag, The intrinsic-extrinsic dichotomy: Toward conceptual clarity, Academy of Management review, 2(3), 496500,1977 .

[19] R. M. Ryanand E. L. Deci, Intrinsic and extrinsic motivations: Classic definitions and new directions, Contemporary educational psychology, 25(1), 54-67, 2000.

[20] A. M. Grant, Does intrinsic motivation fuel the prosocial fire? Motivational synergy in predicting persistence, performance, and productivity, Journal of applied psychology, 93(1), 48,2008.

[21] S.Keller and C. Price, Beyond performance: How great organizations build ultimate competitive advantage, John Wiley \& Sons, 2011.

[22] M. R. Olweny, Students' motivation for architecture education in Uganda, Frontiers of Architectural Research, 6(3), 308-317, 2017.

[23] J. M. Reid, The learning style preferences of ESL students, TESOL quarterly, 21(1), 87-111,1987.

[24] K. L.Stewart and L. A. Felicetti, Learning styles of marketing majors, Educational Research Quarterly, 15(2), 15-23,1992.

[25] C.Riener and D. Willingham, The myth of learning styles, Change, 32-35,2010.

[26] R. Dunn, J. S.Beaudry, and A. Klavas, Survey of research on learning styles, California Journal of Science Education II (2), 2002.

[27] L. Dunegan, An investigation of multiple intelligences: Developing an indicator of learning styles for vocational education and traditional students (Doctoral dissertation, Capella University),2007.

[28] M. Willisand V. K. Hodson, Discover Your Child's Learning Style: Children Learn in Unique Ways--here's the Key to Every Child's Learning Success, Prima Lifestyles, 1999. 
DOI: $\underline{10.51386 / 25815946 / \mathrm{ijsms}-\mathrm{v} 4 \mathrm{i} 4 \mathrm{p} 107}$

Volume: 4 Issue: 4

July to August 2021

https://www.ijjsmsjournal.org

[29] P. Miller, Learning Styles: The Multimedia of the Mind. Research Report,2001.

[30] A. Mackay, Motivation, ability and confidence building in people, Routledge,2010.

[31] S. Byrnes, Assimilative Domain Proficiency and Performance in Chemistry Coursework (Doctoral dissertation), Available from ProQuest Dissertation and Theses databases. (UMI No.3397866), 2010.

[32] A. M. Lisle, Assessing learning styles of adults with intellectual difficulties, Journal of Intellectual Disabilities, 11(1), 23-45,2007.

[33] T.Ngocand S. Samad, A qualitative case study into exploring the learning styles and learning strategies of non-English major Vietnamese college students, Universal Journal of Educational Research, 8(1A), 76-86,2020.

[34] J. W. Creswell, V. L.P. Clark, M. L.Gutmann, and W. E. Hanson, An expanded typology for classifying mixed methods research into designs, A. Tashakkori y C. Teddlie, Handbook of mixed methods in social and behavioral research, 209-240, 2003.

[35] L. T. Carr, The strengths and weaknesses of quantitative and qualitative research: What method for nursing? Journal of Advanced Nursing, 20(4), 716-721,1994.

[36] P.Connolly, Quantitative data analysis in education: A critical introduction using SPSS, London \& New York, NY: Routledge,2007.

[37] R. L. Oxford, Language Learning Strategies: What Every Teacher Should Know. Newburg House/Harper \& Row, New York. Now Boston: Heinle\&Heinle, 1990

[38] C. C. Park, Learning style preferences of Asian American (Chinese, Filipino, Korean, and Vietnamese) students in secondary schools, Equity and Excellence in Education, 30(2), 68-77,1997.

[39] S. A.Burksand T. G. Barrett, Student characteristics and activity choices of college freshmen and their intent to persist in religiously affiliated institutions, Christian Higher Education, 8(5), 351-392,2009.

[40] H.Phuong, Gamified Learning: Are Vietnamese EFL Learners Ready Yet?, International Journal of Emerging Technologies in Learning (iJET), 15(24), 242-251,2020.

[41] H. V. T. Le, Using Group Oral Presentations as a Formative Assessment in Teaching English for Vietnamese EFL Students, In 17th International Conference of the Asia Association of Computer-Assisted Language Learning (AsiaCALL 2021) (pp. 288-296), Atlantis Press, March,2021.

[42] A. A. M. Martadiani, I. S. A. Aziz, and D. A. N.Widari, The Influence of Lecturer Competence, Self-Efficacy and Motivation on Student Achievement of the Faculty of Economics and Business, Warmadewa University, International Journal of Science and Management Studies (IJSMS), v4(i4), 52-59, 2021. 